\title{
Marine litter at (Al-Ghandoor area) the most northern part of the Jordanian coast of the Gulf of Aqaba, Red Sea
}

\author{
Tariq Al-Najjar $^{{ }^{*}}$, Abd Al-Wahab Al-Shiyab ${ }^{2}$ \\ ${ }^{1}$ Faculty of Marine Sciences, Department of Marine Biology, Jordan University, Aqaba Branch, Aqaba, Jorden; \\ ${ }^{*}$ Corresponding Author: t.najjar@ju.edu.jo \\ ${ }^{2}$ Marine Science Station, Jordan University/Yarmouk University, Aqaba, Jorden.
}

Received 1 October 2011; revised 5 November 2011; accepted 15 November 2011.

\begin{abstract}
Composition and abundance of submerged marine litter at one selected site within a coral reef area along the Jordanian coast of the Gulf of Aqaba has been estimated. The litter was collected in a clean up voluntarily campaigns that took place in the period 19 September 2006. A total of 14,613 items weighing $4112.2 \mathrm{~kg}$ were collected during the survey. Mean litter density in the individual sampling sites varied between about 1 and 6 items $/ \mathrm{m}^{2}$ with an over all mean density of 2 items $/ \mathrm{m}^{2}$. The mean weight of the collected items per sampling site varied between 0.06 and $1.81 \mathrm{~kg} / \mathrm{m}^{2}$ with an overall mean of $0.85 \mathrm{~kg} / \mathrm{m}^{2}$. Cans accounted for $41 \%$ of the collected items, plastic was the second most popular $(38 \%)$ while glass litter was the third most abundant item (17\%). By comparison, other items formed only $4 \%$ of the total items collected during the campaigns. Approximately $46 \%$ of the plastic litter consisted of fragments followed by bottles bags and containers (18\%). Potential sources are pointed out and recommendations and actions to deal with the problem are suggested.
\end{abstract}

Keywords: Marine Debris; Marine Litter; Gulf of Aqaba; Clean up Dive

\section{INTRODUCTION}

Marine litter composition, abundance, distribution and quantification of the types and amounts on beaches have been studied and reported from many parts of the world [1-19].

The main sources of marine litter are the: sea-borne sources which include industrial and domestic wastes disposed off at sea, and the land-based sources which include litter originating from visitors to the coast, whether small items such as drink cans and containers, or those originating from the unauthorized dumping of large items such as landfill materials [5,16,20-28].

Benthic marine debris may also have detrimental effect on coral reef ecosystem by damaging of corals covered by debris [29]. Movement of fishing gear can cause damage to coral substrate comprising the reef structure; some nets recovered had $20 \%$ of their weight attributable to broken coral fragments. Movement of fishing gear across shallow reefs destroys other benthic reef flora and fauna and entangles macrofauna, including threatened and endangered species [30].

\section{MATERIALS AND METHODS}

\subsection{Clean Up Sites}

Submerged debris was removed and collected from one underwater site within coral reef areas at the most northern tip of the Jordanian coast of the Gulf of Aqaba (Figure 1). Site was selected based on the type of usage and activities that take place at the site. The North beach (Al-Ghandoor) is located at the most northern part of the Gulf of Aqaba, and characterized by heavy tourism activities and by the presence of many public cafés. However, diving, snorkeling and swimming activities are permitted within this site.

\subsection{Method of Clean Up Survey}

The clean up campaign has been conducted in 16 September 2006. Site was divided into one segments/transect (one squares) of $20 \mathrm{~m} \times 20 \mathrm{~m}$; the total area of site was $400 \mathrm{~m}^{2}$. All litter at the site was collected by 60 SCUBA divers moving along the transect, to ensure that 


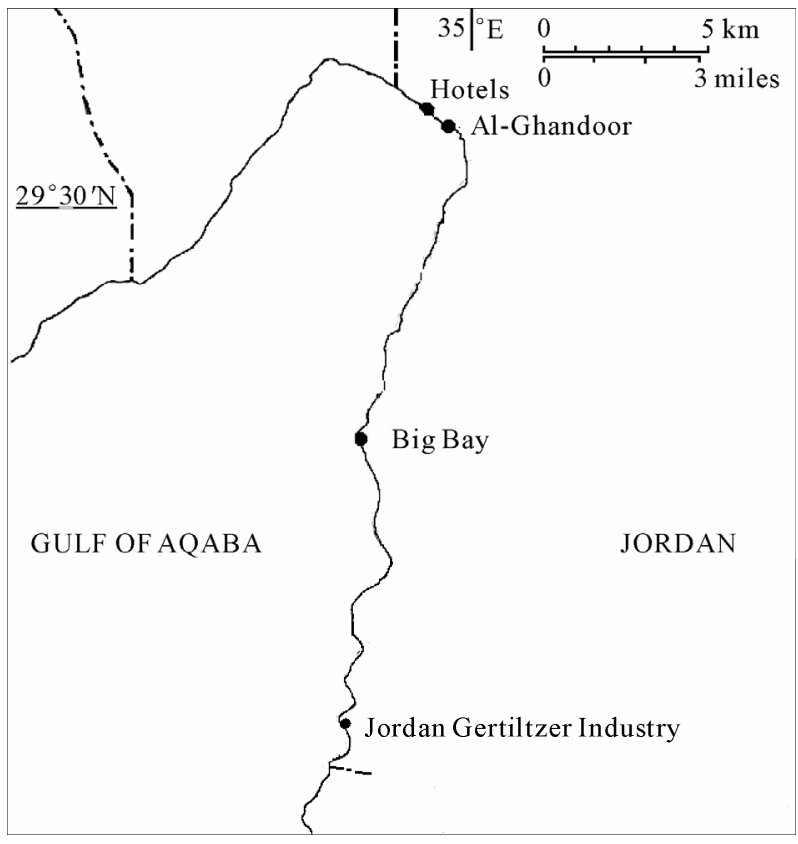

Figure 1. Clean up dive site, along the Jordanian coast of the Gulf of Aqaba, Red Sea.

all debris within the transect were collected. Divers pick up debris free from the substrate/sea bottom using care to avoid disturbing the sea bottom agitating the sediments, stepping on marine biota or causing coral damage. Pieces of nets found fully incorporate into the reef structure, and no longer an entanglement hazard, were left in place to avoid additional coral damage and preserve associated-coral growth. Removed debris was lifted to the sea surface by using lifting bags carried by the two divers. Snorklers on the sea surface were helping in collecting the filled bags. All debris was then transported to the beach where it was sorted into broad categories: glass, metals, plastic, cardboard, rubber, fishing gear and others. Each category was further sorted into more subcategories: cups, bags, containers, etc., which were counted and weighed. Total amount of debris in each site was determined by summing the amount of litter for each liters bag. Table 1 shows the total number of divers participated in each clean up dive.

\section{RESULTS}

A total of 14,613 litter items weighing $4112.2 \mathrm{~kg}$ were collected during the clean up of Al-Ghandoor site. In terms of counts per $\mathrm{m}^{2}\left(36.5 \mathrm{item} / \mathrm{m}^{2}\right)$, mean counts of litter in the site varied from 0.008 to $15 \mathrm{item} / \mathrm{m}^{2}$ with an overall mean of 3.04 item $/ \mathrm{m}^{2}$ for the whole study area (Figure 2).

In terms of weight $\left(10.28 \mathrm{~kg} / \mathrm{m}^{2}\right)$, the mean weight of the items collected from the sampling sites varied from $0.055-2.98 \mathrm{~kg} / \mathrm{m}^{2}$, with an overall mean of $0.86 \mathrm{~kg} / \mathrm{m}^{2}$
Table 1. Clean up participants and total number of divers participated in clean up dive.

\begin{tabular}{lc}
\hline \multicolumn{1}{c}{ Clean up participants } & Number of Divers \\
\hline Aqaba Marine Park Center of ASEZA & 4 \\
Royal Navy & 20 \\
Marine Science Station & 6 \\
Jordan Royal Ecological Diving Society (JREDS) & 10 \\
Private diving centers & 20 \\
Total & 60 \\
\hline
\end{tabular}

for the whole study area (Figure 3).

When the type of litter was considered metal cans showed the highest litter occurrence $41 \%$ compared with the rest items (Figure 4). Plastic accounted for 38\% of the items counted, while total glass was the third most important item and constituted $17 \%$. Other item was the fourth most important item. Within the plastics when the weight is considered, about $36 \%$ consisted of bottles and $36 \%$ of Fragments, whereas, containers bags accounted for $28 \%$ and $2 \%$ respectively (Figure 5).

\section{DISCUSSION}

A significant amount of literature is dedicated to beach litter types, distributions, and temporal variations [7], but almost no exist with respect to submerged (benthic) marine litter by the 1990s [31]. In comparison, only few studies have recently been published with regard to submerged and subsurface nearshore litter on the global level ([20,32-35]).

Searching the literature, we did not fined a single report on this subject in the whole Red Sea region including the Gulf of Aqaba. The first single published report was by [36] on the litter pollution on the Jordanian shores of the Gulf of Aqaba. In that report we hinted very briefly to the presence of marine debris in the coastal waters and among the corals of the Jordanian side of the Gulf of Aqaba.

Knowing the seriousness of the problem we felt it is urgent to follow up this issue, investigate the magnitude of the problem, and try to provide information that can help the official authorities and decision makers to dealing with the issue and solving the problems related to it. Therefore, we participated in the clean up dive campaigns, identified, categorized, and enumerated the collected items and finally reported the results of the campaigns.

The results indicate a high diversity of litter collected from the studied site. The most likely explanation for this diversity is related to the uses of the selected site. The higher counts of items found at Al-Ghandoor site is 


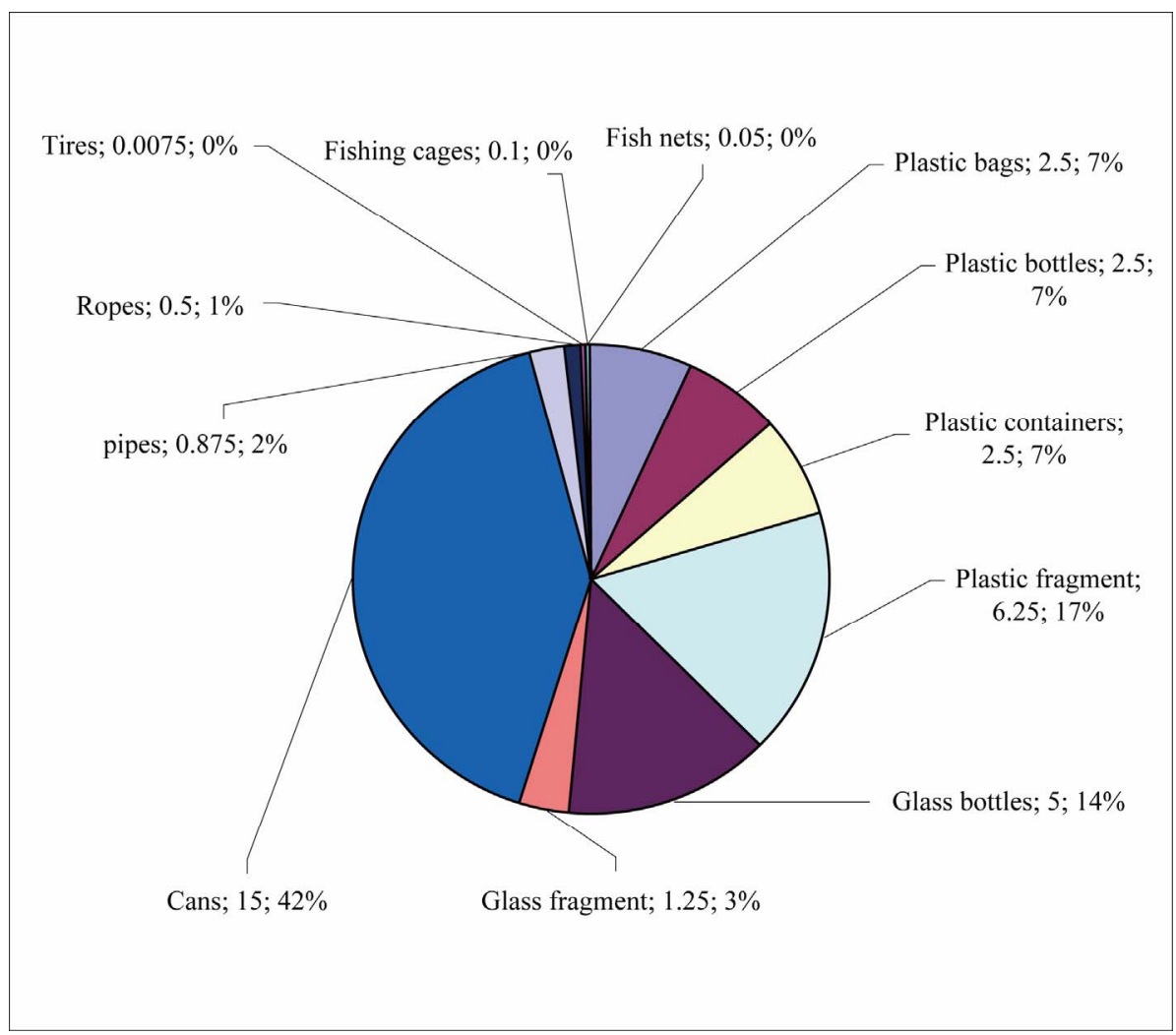

Figure 2. Total number of litter per $\mathrm{m}^{2}$ and its percentage in clean up site.

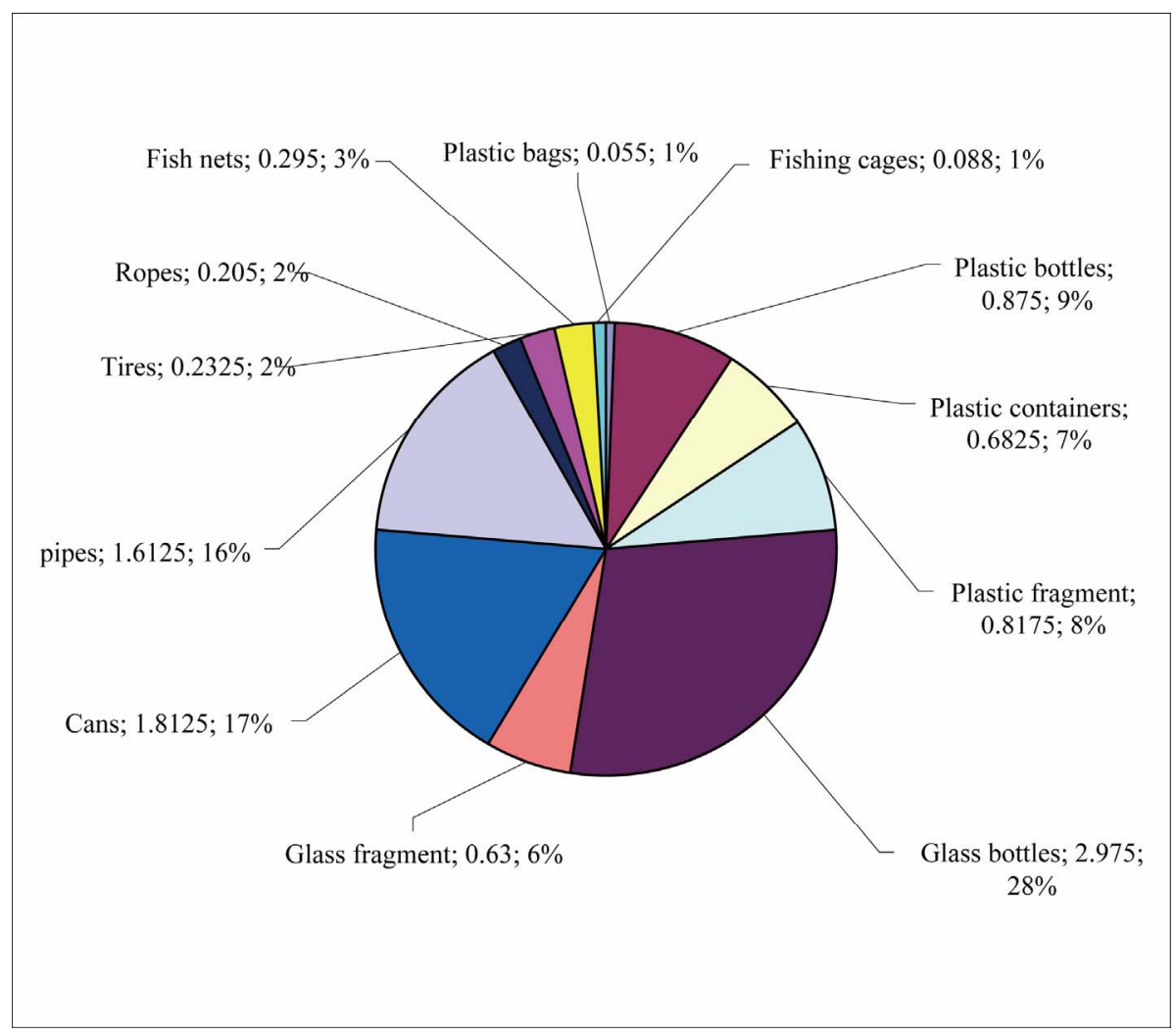

Figure 3. Total weight $\left(\mathrm{kg} / \mathrm{m}^{2}\right)$ of litter and its percentage in clean up site. 


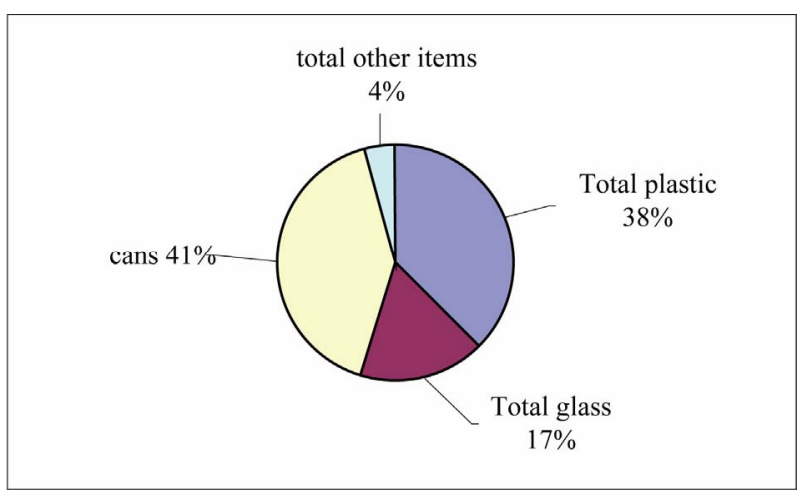

Figure 4. Percentage of litter items collected from different clean up sites.

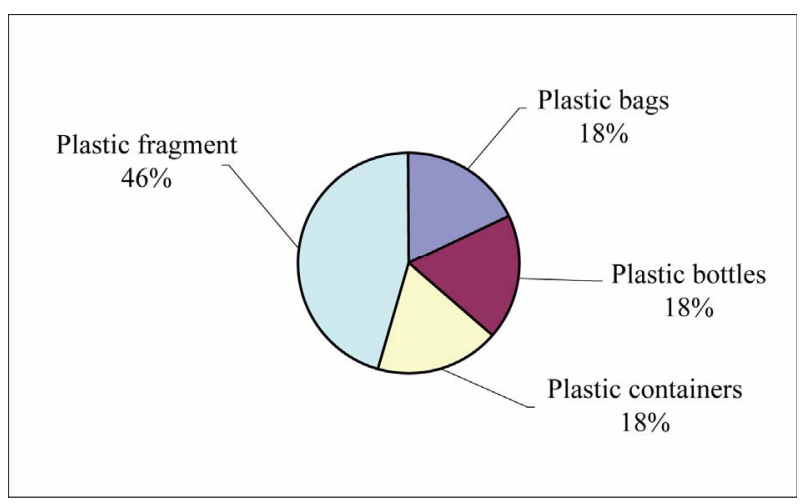

Figure 5. Percentage of plastic litter items collected in the clean up site.

attributed to the fact that this site is popular and most accessible site to local public and tourists. The litter items found in the waters of these sites, particularly plastic Bottles and bags, metal cans, and pieces of glass are associated with and indicative of the activities of beach goers.

Variations in the distribution and differences in the composition of debris on recreation and non-recreation beaches of the same study area have been noted and discussed by [36] who indicated that the waste discarded from the Aqaba (Jordan)-Nweibi (Egypt) ferry boat is a major source of litter found on the beach of the protected area within the Marine Science Station beach at the southern edge of the passengers port.

The results in the present study indicated that metal cans and plastics were the numerically dominant litter item within the whole study area followed by glass was the third dominant item. These results are similar to what has been reported from many parts of the world. Among these are the results of [7] who studied the submerged marine debris at Curacao West Indies waters, and found that plastics were the dominant litter items $(47 \%$ of the total debris) followed by glass and metals. Similarly, [37] found that plastic was the most abundant debris $(79 \%$ -
$83 \%)$ followed by metal $(7.5 \%-8.5 \%)$ in two enclosed gulfs in Western Greece. Plastic in a form of bags and bottles were the most common (70\%) submerged debris on the sea floor along the European coast [32]. Plastic and metal were also the most common items of benthic marine debris in many locations surrounding Kodiak Island, Alaska [38]. According to the same report fishery related submerged plastic were also common. Plastics were the most common type of anthropogenic debris on a wide area of the continental shelf of the southern California Bight [35]. [29] reported the results of multiagency divers clean up survey that took place in two northwestern Hawaiian Islands. Fourteen tons of derelict fishing gear was removed in addition to other types of reef debris.

In a previous report on the beach litter of the present study area, we have concluded that most of the litter on the Jordanian coastline of the Gulf of Aqaba results from recreational and shipping activities; it was not easy to differentiate between flotsam and litter left by beach visitors; and that much of the letter onto the beaches was of local land-based or close offshore origin [36]. It is accepted that each of these sources requires a different management action to affect a reduction in marine debris [39].

In the present study, we have tried to benefit from the coordinated efforts of volunteer divers and researcher to clean the Al-Ghandoor the most popular area for the tourist and the local visitors from debris in waters of less than $[29,36]$, and collect information on their types, and distribution. The results of the present and other multiagency cleanup campaigns [39] show that these campaigns are useful and can help producing good scientific data and reports, which are useful for decision-makers and environmental managers. This is also true for those in the Red Sea and Gulf of Aqaba region, which has been designated under the terms of regulation 10 of MARPOL and its Annexes as a "special area". Annex V, in particular prohibits and restricts the disposal of all garbage from ships in any special area. However, it is believed that the following actions can be useful in reducing the debris in the study area.

- Educational programs that are directed at reducing all litter including land-based sources.

- Educational and public awareness programs targeting users of the marine environment including commercial and recreational fishers, boaters including glass boats, beach goers, divers, school teachers, students.

- Educational tools must be made widely available and distributed free to all targeted users. Tools may include brochures, leaflets, stickers and posters.

- Multi-agency clean up campaigns must be maintained the year around and data of the campaigns made avail- 
able to the participants, decision makers, stakeholders, and the public.

- Put suitable regulations and enforce the already adopted ones to ensure the compliance of marine and each user with these regulations.

- Cooperation and coordination with other riparian countries along the Red Sea and the Gulf of Aqaba to take the necessary measures and actions including cleaning campaigns that can help keeping the Gulf of Aqaba waters and reefs free from marine debris.

\section{CONCLUSIONS}

Composition and abundance of submerged marine litter at one selected site (Al-Ghandoor) within a coral reef area along the Jordanian coast of the Gulf of Aqaba has been estimated. The results indicated that metal cans and plastics were the numerically dominant litter item within the whole study area followed by glass was the third dominant item. The high diversity of litter collected from the study site is attributed to its popular and most accessible site for local public and tourists. The results of the present and other multi-agency cleanup campaigns show that these campaigns are useful and can help producing good scientific data and reports, which are useful for decision-makers and environmental managers.

\section{ACKNOWLEDGEMENTS}

The authors acknowledge the staff of The Royal Marine Conservation Society of Jordan (JREDS), especially Mr. Faisal Abu-Alsondus, the Aqaba Diving Centers, the Aqaba Special Economic Zone Authority (AZEZA), the Aqaba Marine Park and the Marine Science Station (MSS), and Jordanian Military force for their great efforts in the undertaking of the underwater clean up dive. This was supported by the NATO projects (SfP 982161 and 981883).

\section{REFERENCES}

[1] Corbin, C.J. and Singh, J.G. (1993) Marine debris contamination of beaches in St Lucia and Dominica. Marine Pollution Bulletin, 26, 325-328. doi:10.1016/0025-326X(93)90575-5

[2] Garrity, S.D. and Levings, S.C. (1993) Marine debris along the Caribbean coast of Panama. Marine Pollution Bulletin, 26, 317-324. doi:10.1016/0025-326X(93)90574-4

[3] Golik, A. (1997) Debris in the Mediterranean Sea: Types, quantities, and behavior. In: Coe, J.M. and Rogers, D.B. Eds., Marine Debris: Sources, Impacts, and Solutions, Springer, New York, 7-14.

[4] Golik, A. and Gertner, Y. (1992) Litter on the Israeli coastline. Marine Environmental Research, 33, 1-15. doi:10.1016/0141-1136(92)90002-4

[5] Debrot, A.O., Tiel, A.B. and Bradshshaw, J.E. (1999). Beach debris in Curacao. Marine Pollution Bulletin, 38, 795-801. doi:10.1016/S0025-326X(99)00043-0
[6] Gregory, M.R. and Rayan, P.G. (1997) Pelagic plastics and other seaborne persistent synthetic debris: A review of Southern Hemisphere perspectives. In: Coe, J.M. and Rogers, D.B., Eds., Marine Debris: Sources, Impacts and Solutions, Springer-Verlag, New York, 49-66.

[7] Madzena, A. and Lasiak, T. (1997) Spatial and temporal variations in beach litter on the Transkei coast of South Africa. Marine Pollution Bulletin, 34, 900-907. doi:10.1016/S0025-326X(97)00052-0

[8] Ribic, C.A., Johnson, S.W. and Cole, C.A. (1997) Distribution, type, accumulation, and source of marine debris in the US, 1989-1993. In: Coe, J.M. and Rogers, D.B., Eds., Marine Debris: Sources, Impacts and Solutions, Springer, New York, 35-47.

[9] Ribic, C.A. (1998) Use of indicator items to monitor marine debris on a New Jersey beach from 1991-1996. Marine Pollution Bulletin, 36, 887-891. doi:10.1016/S0025-326X(98)00064-2

[10] Ryan, P.G. (1987) The effects of ingested plastic on seabirds: Correlations between plastic load and body conditions. Environmental Pollution, 46, 119-125. doi:10.1016/0269-7491(87)90197-7

[11] Walker, T.R., Reid, K., Arnould, J.P.Y. and Croxall, J.P. (1997) Marine debris surveys at Bird Island, South Gorgia 1990-1995. Marine Pollution Bulletin, 34, 61-65. doi:10.1016/S0025-326X(96)00053-7

[12] Williams, A.T. and Tudor, D.T. (2001) Litter burial and exhumation: Spatial and temporal distribution on a Cobble Pocket beach. Marine Pollution Bulletin, 42, 10311039. doi:10.1016/S0025-326X(01)00058-3

[13] Khordagui, H.K. and Abu-Hilal, A.H. (1994) Man-made litter on the shores of the United Arab Emirates on the Arabian Gulf and the Gulf of Oman. Water, Air and Soil Pollution, 76, 343-352. doi:10.1007/BF00482711

[14] Khordagui, H.K. and Abu-Hilal, A.H. (1994) Industrial plastic on the southern beaches of the Arabian Gulf and western beaches of the Gulf of Oman. Environmental Pollution, 84, 325-327.

doi:10.1016/0269-7491(94)90143-0

[15] Shiber, J.G. (1979) Plastic pellets on the coast of Lebanon. Marine Pollution Bulletin, 10, 28-30. doi:10.1016/0025-326X(79)90321-7

[16] Shiber, J.G. (1987) Plastic pellets and tar on Spains Mediterranean beaches. Marine Pollution Bulletin, 18, 84-86. doi:10.1016/0025-326X(87)90573-X

[17] Shiber, J.G. and Barrales-Reinda, J.M. (1991) Plastic pellets, tar, and megalitter on Beirut beaches, 1977-1988. Environmental Pollution, 71, 17-30. doi:10.1016/0269-7491(91)90041-T

[18] Silva-Iniquez, L. and Fischer, D. W. (2003) Quantification and classification of marine litter on the municipal beach of Ensenada, Baja California, Mexico. Marine Pollution Bulletin, 46, 132-138. doi:10.1016/S0025-326X(02)00216-3

[19] Kusui, T. and Noda, M. (2003) International survey on the distribution of stranded and buried litter on beaches along the Sea of Japan. Marine Pollution Bulletin, 47, 175-179. doi:10.1016/S0025-326X(02)00478-2

[20] Nagelkerken, I., Wiltjer, G.A.M.T., Debrot, A.O. and Pors, L.P.J.J. (2001) Baseline study of submerged marine debris at beaches in Curacao, West Indies. Marine Pollution Bulletin, 24, 786-789. 
doi:10.1016/S0025-326X(01)00091-1

[21] Wilber, R.J. (1987) Plastic in the North Atlantic. Oceanus, 30, 61-68.

[22] Pruter, A.T. (1987) Sources, quantities and distribution of persistent plastics in marine environment. Marine Pollution Bulletin, 18, 305-310. doi:10.1016/S0025-326X(87)80016-4

[23] Price, A.R.G., Whitehall, T.J. and Bernard, S.M. (1987) Occurrence of tar and other pollution on the Saudi Arabia shores of the gulf. Marine Pollution Bulletin, 18, 650651. doi:10.1016/0025-326X(87)90399-7

[24] Vauk, G.J.M. and Schrey, E. (1987) Litter pollution from ships in the German Bight. Marine Pollution Bulletin, 18, 316-319. doi:10.1016/S0025-326X(87)80018-8

[25] Polglaze, J. (2003) Can we always ignore ship-generated food waste? Marine Pollution Bulletin, 46, 33-38. doi:10.1016/S0025-326X(02)00324-7

[26] Horsman, P.V. (1982) The amount of garbage pollution from merchant ships. Marine Pollution Bulletin, 13, 167169. doi:10.1016/0025-326X(82)90088-1

[27] Shaw, D.G. (1977) Pelagic tar and plastic in the Gulf of Alaska and Bering Sea: 1975. Science of the Total Environment, 8, 13-20. doi:10.1016/0048-9697(77)90058-4

[28] Shaw, D.G and Mapes, G.A. (1979) Surface circulation and distribution of pelagic tar and plastic. Marine Pollution Bulletin, 10, 160-162. doi:10.1016/0025-326X(79)90421-1

[29] Donohue, M.J., Boland, R.C., Sramek, C.M. and Antonelis, G.A. (2001) Derelict fishing gear in the Northwestern Hawaiin Islands: Diving survey and debris removal in 1999 confirm threat to coral ecosystems. Marine Pollution Bulletin, 42, 1301-1312. doi:10.1016/S0025-326X(01)00139-4

[30] Jones, M.M. (1995) Fishing debris in the Australian marine environment. Marine Pollution Bulletin, 30, 25-33. doi:10.1016/0025-326X(94)00108-L

[31] Williams, A.T., Simmons, S.L. and Fricker, A. (1993) Off-shore sinks of marine litter: A new problem. Marine Pollution Bulletin, 26, 404-405.
doi:10.1016/0025-326X(93)90192-M

[32] Galgani, F., Burgeot, T., Bocquene, G., Vencent, F., Leaute, J.P., Labastie, J., Forest, A. and Guichet, R. (1995a) Distribution and abundance of debris on the continental shelf of the Bay of Biscay and in Seine Bay. Marine Bullution Bulletin, 30, 58-62.

[33] Galgani, F., Jaunet, S., Campillo, A., Guenegen, X. and Hiss, E. (1995b) Distribution and abundance of debris on the continental shelf of the north-western Mediterranean Sea. Marine Pollution Bulletin, 30, 713-717. doi:10.1016/0025-326X(95)00055-R

[34] Galil, B.S., Golik, A. and Türkay, M. (1995) Litter at the bottom of the sea: A seabed survey in the Eastern Mediterranean. Marine Pollution Bulletin, 30, 22-24. doi:10.1016/0025-326X(94)00103-G

[35] Moore, S.L. and Allen, M.J. (2000) Distribution of anthropogenic and natural debris on the mailand shelf of the Southern California Bight. Marine Pollution Bulletin, 40, 83-88. doi:10.1016/S0025-326X(99)00175-7

[36] Abu-Hilal, A.H. and Al-Najjar. T. (2004) Litter pollution on the Jordanian shores of the Gulf of Aqaba (Red Sea). Marine Environmental Research, 58, 39-63. doi:10.1016/i.marenvres.2003.12.003

[37] Stefatos, A., Charalampakis, M., Papatheodorou, G. and Ferentinos, G. (1999) Marine debris on the sea floor of the Mediterranean Sea: Examples from two enclosed Gulfs in Western Greece. Marine Pollution Bulletin, 36, 389-393. doi:10.1016/S0025-326X(98)00141-6

[38] Hess, N.A., Ribic, C.A. and Vining, I. (1999) Benthic marine debris, with an emphasis on fishery-related items, surrounding Kodiak Island, Alaska, 1994-1996. Marine Pollution Bulletin, 38, 885-890. doi:10.1016/S0025-326X(99)00087-9

[39] Moore, S.L., Gregorio, D., Carreon, M., Weisberg, S.B. and Leecaster, M.K. (2001) Composition and distribution of beach debris in Orange Country, California. Marine Pollution Bulletin, 42, 241-245. doi:10.1016/S0025-326X(00)00148-X 